\title{
TOWARDS THE CREATION OF A DECISION SUPPORT SYSTEM TOOL FOR THE PRELIMINARY RISK ASSESSMENT OF BROWNFIELD SITES
}

\author{
CHARF E. MAHAMMEDI ${ }^{1}$, LAMINE MAHDJOUBI ${ }^{1}$, COLIN A. BOOTH ${ }^{1} \&$ TALIB E. BUTT $^{2}$ \\ ${ }^{1}$ Centre for Architecture and Built Environment Research (CABER), University of the West of England, UK \\ ${ }^{2}$ Faculty of Engineering and Environment, Northumbria University, UK
}

\begin{abstract}
Brownfield sites always raise concern for the health and safety of site workers involved in site renovations and developments and, subsequently, for the residents or occupants of the sites. As a minimum, a preliminary risk assessment is necessary to determine whether a brownfield site is contaminated and, if so, ensuring any redevelopment is safe and suitable for its proposed use. Despite growing interest in the progression of risk assessment tools, there are limited instruments available for brownfield site assessors to consult when conducting investigations at the preliminary risk assessment stage. This study presents a conceptual framework that ultimately aims to create a web-based decision support system (DSS) for the preliminary risk assessment of brownfield sites. This is based on a pollutant linkage model (Source-Pathway-Receptor). The proposed framework aids the identification of health and safety hazards and, in doing so, it addresses the challenges facing those persons dealing with the decision-making on brownfield site developments. Moreover, the framework enables them to determine the most appropriate remediation strategy(ies) to halt pollutant linkages, promote safer developments and minimise the risks to future occupants of brownfield sites and neighbouring lands. Keywords: brownfield sites, contaminated sites, preliminary risk assessment, health and safety, pollutant linkage.
\end{abstract}

\section{INTRODUCTION}

Constraints on the use of green spaces for development purposes has meant brownfield sites have become increasingly popular for redevelopment in recent years, especially in places where demand for residential and commercial property is high [1]. The UK government is committed to prioritising the development of brownfield sites. The reuse of brownfield lands has been a major policy objective in England since the late 1990s, aimed at reducing urban sprawl and minimising greenfield development, as well as contributing to a more compact form of urban development [2]. This supports SDG (sustainable development goal) 11 Indicators for Sustainable Cities and Communities, which requires the best information and communication technologies [3].

In 2012, there were approximately 45,120 ha of publicly identified brownfield sites in England, including all vacant and derelict land, which could be reused [4]. However, as brownfield sites have had previous use(s) they may contain hazards, which can pose potential risks to human health and the built environment [5], [6]. For instance, soil contaminated by heavy metals are widely known to have a detrimental effect on human health [7], [8]. In addition, from a developer's viewpoint Charles et al. [9] recognises that buildings being constructed on brownfield sites often lead to construction cost increases and construction delays. Similarly, in some cases, issues may only occur many years after a building has been completed, such as new housing developments where previous usage has left a relic of physical, chemical and biological hazards [10], [11].

Prior to the redevelopment of any brownfield site it is important to conduct a preliminary risk assessment. A specialist is commonly employed to provide an independent professional report about the health and safety of a site, in terms of risk to human health and the built 
environment, by identifying actual or potential hazards of the site [12]. Addressing the complex parameters involved in the risk assessment process comprehensively and successfully requires expertise and knowledge from a number of disciplines, ranging from geotechnical engineers to geochemical scientists [13].

This study presents a framework to develop a decision support system (DSS) for preliminary brownfield site risk assessment. In doing so, the DSS will assist persons to better understand the potential health and safety hazards associated with the development of brownfield sites.

\section{PRACTICE-BASED DESIRE FOR A DSS TOOL}

Risk assessments can be expensive, resource intensive, and time consuming when examining the large number of sites at the regional or national scales [14], [15]. Therefore, inexpensive and easy to use tools designed to aid the assessment of potential brownfield site risks are highly desirable. For this purpose, it is very important to have a DSS tool that indicates what further information is needed or if a site needs to be kept under review. For instance, a developer may decide to develop brownfield land on the basis of a preliminary risk assessment alone without any further investigation and detailed quantitative risk assessment, provided the developer is confident that any contamination present can be addressed using appropriate measures, and the acquisition brings wider commercial benefits. Table 1 shows the issues that can be addressed by developing a DSS tool for preliminary risk assessment of brownfield sites.

\section{METHODOLOGY TO DEVELOP THE DSS TOOL}

An overview of the process for creating the DSS is detailed beneath (Fig. 1). This shows a four-stage process, which includes both quantitative and qualitative methods. Mixed methods are used to provide both breadth and depth in collecting, analysing and understanding the data that will help to create the DSS tool. Stage 1 involves the creation of a conceptual framework using existing literature to guide the development of the DSS tool. Stage 2 uses a questionnaire to subject experts validate or sign-off the literature findings. Stage 3 the development of the DSS tool. Finally, Stage 4, uses case studies and further validation exercises to complete the approval of the DSS tool. This paper provides insights to Stage 1 . The other stages and the DSS tool will be reported in future works.

\section{DEVELOPMENT OF THE CONCEPTUAL FRAMEWORK}

Under Part 2A of the Environment Protection Act 1990, the risk assessment should identify the potential sources, pathways and receptors and evaluate the risks. Each of these elements can exist independently, but they create a risk only where they are linked together. This kind of linked combination of contaminant-pathway-receptor is described as a pollutant linkage (Fig. 2) [30]. These are the three fundamental components to any assessment and management of land contamination risks in many European countries [33]. However, this concept will enable brownfield site assessor to determine whether more detailed investigation is required, or whether any proposed remediation is satisfactory [34].

A number of studies [30], [35], [36] established the necessary information to conduct a preliminary risk assessment as follow:

1. Building and other structure

2. Current land use

3. Future site use

4. History of the site

5. Site geological 
6. Site hydrology

7. Topography

8. Underground services

Table 1: Proposed benefits of conducting a preliminary health and safety risk assessment of brownfield sites.

\begin{tabular}{|c|c|c|}
\hline & Benefits of preliminary health and safety risk assessment & References \\
\hline 1. & $\begin{array}{l}\text { Identifying the hazards at the early stage will prevent time delay } \\
\text { for additional investigations. }\end{array}$ & {$[14],[16]$} \\
\hline 2. & Prevent misunderstanding at later stage in the development. & {$[17],[18]$} \\
\hline 3. & $\begin{array}{l}\text { Avoid delays in the development stage through unexpected or } \\
\text { accidental contamination. }\end{array}$ & [19] \\
\hline 4. & $\begin{array}{l}\text { Help developers identify and respond to any key issues that could } \\
\text { affect planning. }\end{array}$ & {$[16],[20]$} \\
\hline 5. & $\begin{array}{l}\text { Help developers identify and respond to any key issues that could } \\
\text { affect permitting decisions when they are locating and designing } \\
\text { developments. }\end{array}$ & {$[21],[22]$} \\
\hline 6. & $\begin{array}{l}\text { Help developers to take adequate decisions related to the } \\
\text { acquisition of the site. }\end{array}$ & {$[23]$} \\
\hline 7. & $\begin{array}{l}\text { Help developers to take adequate decisions related to future use } \\
\text { of the land. }\end{array}$ & {$[24],[25]$} \\
\hline 8. & $\begin{array}{l}\text { Help developers to take adequate decisions related to making } \\
\text { contract for the site acquisition or development, etc. }\end{array}$ & {$[12],[20]$} \\
\hline 9. & $\begin{array}{l}\text { Improve predictability of future issues related the development of } \\
\text { the site. }\end{array}$ & {$[20],[26]$} \\
\hline 10. & $\begin{array}{l}\text { Improve the communication between the developer, local } \\
\text { authorities, consultancies and clients allowing for better decision } \\
\text { making, which helps to improve quality and mitigate risk. }\end{array}$ & {$[14],[27]$} \\
\hline 11. & $\begin{array}{l}\text { Fully coordinated design helps to reduce potential risk on site } \\
\text { reconnaissance and investigation. }\end{array}$ & [27], [28] \\
\hline 12. & $\begin{array}{l}\text { Determine the potential of hazard being present and whether } \\
\text { future site investigation in needed. }\end{array}$ & {$[29]-[31]$} \\
\hline 13. & $\begin{array}{l}\text { Determine whether any particular precaution is required during } \\
\text { inspection or investigation. }\end{array}$ & {$[5],[29],[32]$} \\
\hline 14. & $\begin{array}{l}\text { Provide information and about the legal regulation risk and/or } \\
\text { remedial measures. }\end{array}$ & [14] \\
\hline 15. & $\begin{array}{l}\text { Determining the activities processes of the site including the } \\
\text { delivery, storage and handling of raw materials, the disposal of } \\
\text { wastes will help the collect a representative sample to identify } \\
\text { outliers based on the contaminant location. }\end{array}$ & {$[25]$} \\
\hline
\end{tabular}




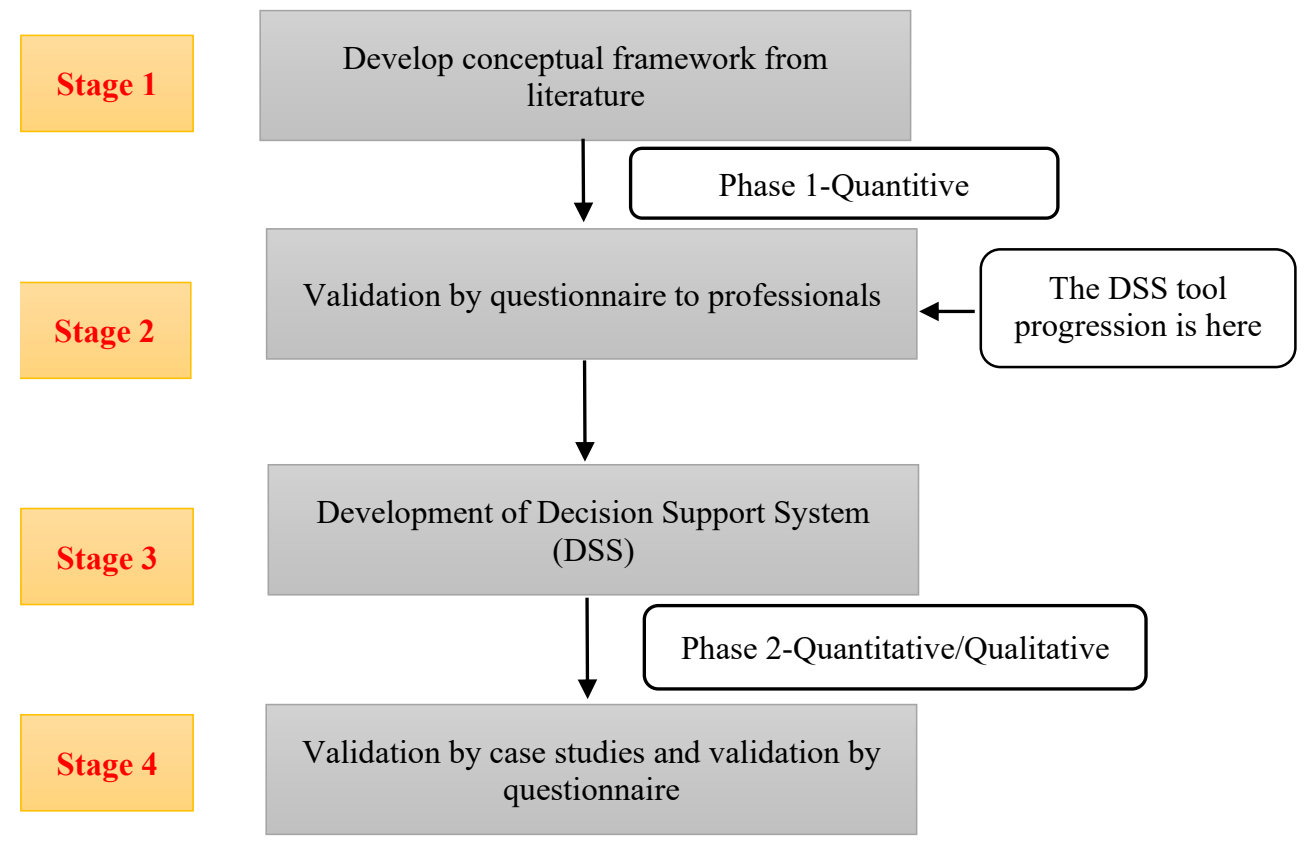

Figure 1: The four stages adopted in the development process of the Decision Support System tool.

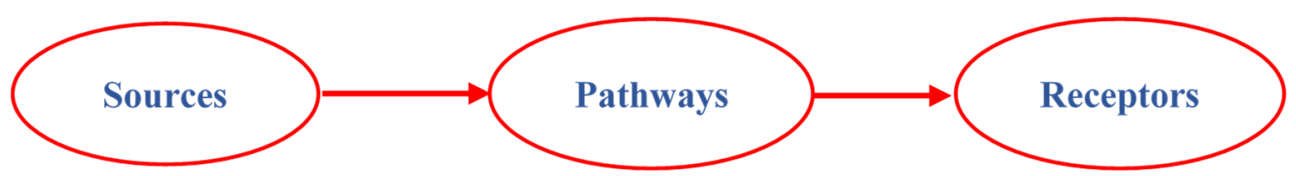

Figure 2: Pollutant linkage concept. (Source: Derived from DEFRA and Environment Agency [30].)

Scientific databases have been created based on the above information needed to identify the link between source of hazards in brownfield sites, pathways and receptors. The databases are used to help in identifying, assessing and rating hazards, where a comprehensive toxicological profile have been created to each contaminant interpret their effects on human health and built environment.

\section{CONCEPTUAL FRAMEWORK}

The framework is a conceptual structure intended to support and guide researchers for the building of a theory of a research study [37], and to allow researchers to intellectually transition from a simple description phenomenon to generalizing about different aspects of that phenomenon. In the context of this research, the developed framework (Fig. 3) is to support and guide the researcher to create the DSS tool. Notwithstanding the proliferation of literature examined, no studies to date have attempted to develop a framework that assist people dealing with brownfield site to better understand risk associated with development of 


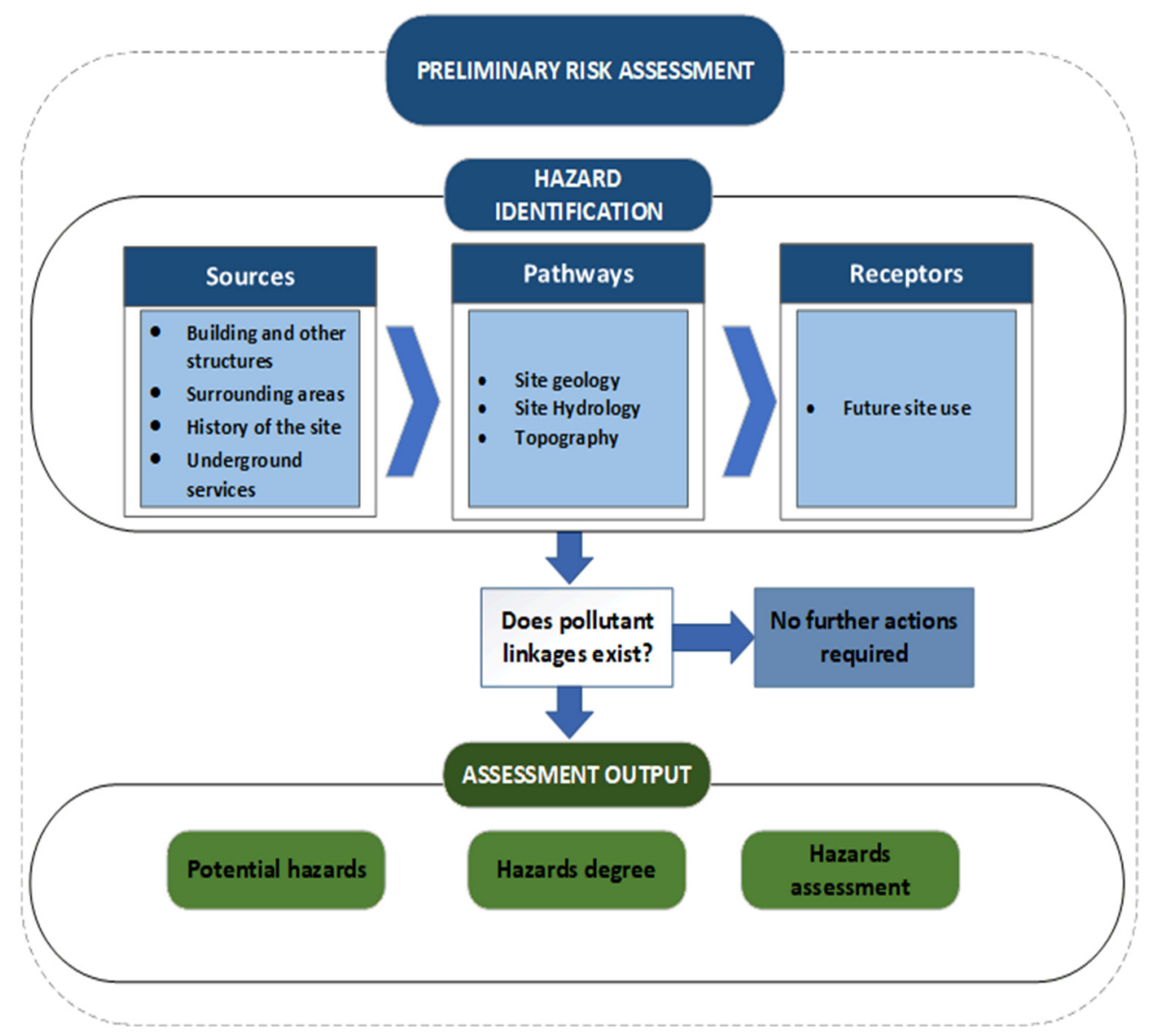

Figure 3: Conceptual framework for preliminary risk assessment of brownfield sites.

this type of sites. Nevertheless, the increasingly widespread use of brownfield sites across countries with rich industrial pasts, coupled with the complexity, highlights the need to first develop a conceptual framework that helps to conduct a preliminary risk assessment.

\section{THE DDS WORKFLOW}

A workflow of the DDS is presented (Fig. 4), which consist of eight steps that are adopted to conduct a preliminary risk assessment for brownfield sites. These steps established to identify the potential sources, pathways and receptors ("pollutant/contaminant linkages") and evaluate the risks.

Source: The first four steps provide a good indication of potential sources and types of hazards likely to be found on site. Three important indicators to assist to identify the source of hazards in brownfield sites: history of the site, surrounding area and the existing of obstructions (i.e. tanks) as result of previous use of the site. The source of hazards in brownfield sites can be classified into three main types, firstly contaminated sites which have left a legacy of contamination from operational activities. Secondly, ground movement 


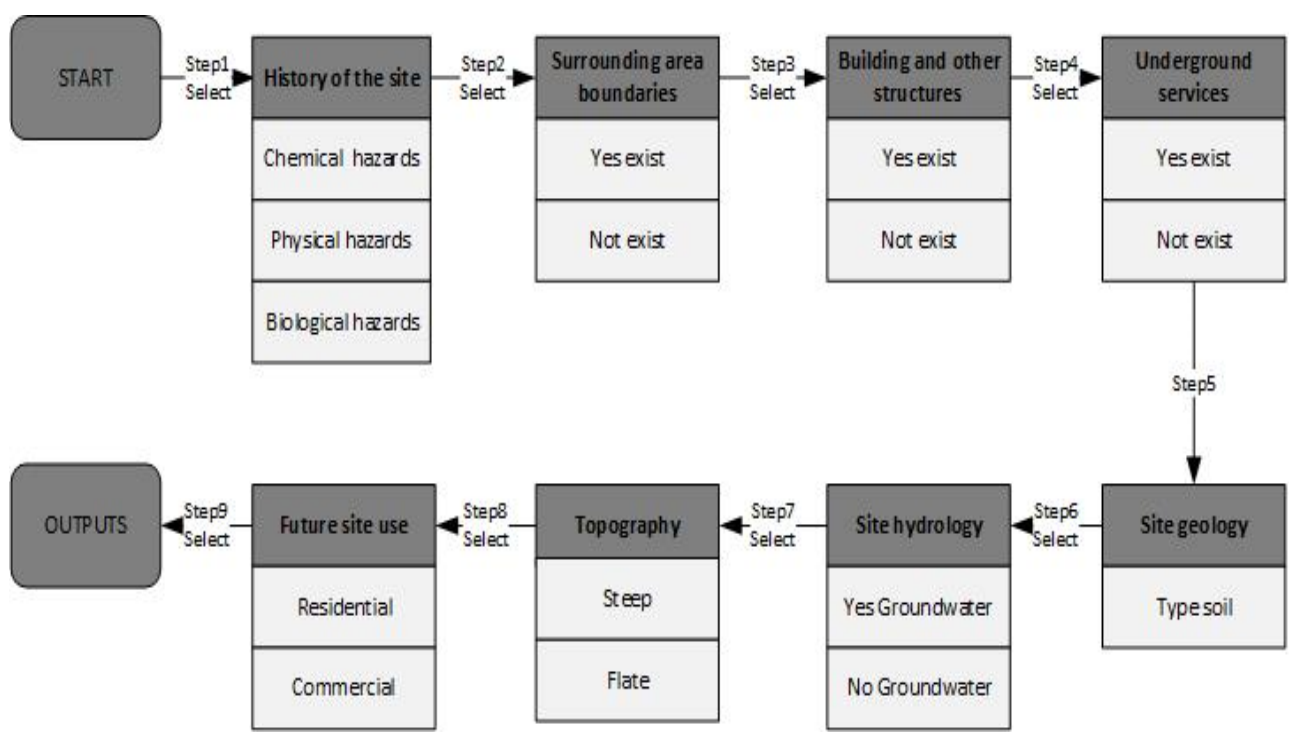

Figure 4: The workflow of the DSS tool.

induced by chemical reactions or issues related to uncontrolled of fill materials. Thirdly, existing buildings in brownfield sites including industrial and commercial buildings arise hazards related to the release of chemical hazards during demolition.

Pathway: Step 6, step 7 and step 8 allow the user to determine the pathways within the preliminary risk assessment involves locating possible routes for migration of contaminants within the site. Creating a knowledge-base for such a task involves capturing information from a range of subject areas, with the aim of presenting the user with a list of possible pathways. On consultation of the technical literature there were three major parameters that were identified to affect the pathway of contaminants: site geology, site hydrology and the topography of the site.

Receptor: Step 9 presents the receptors of hazards in brownfield sites. Receptors of different ages exposed to the same level of contamination have a different reaction because of differences in physiology and behaviour. Therefore, in reviewing the future land use, the assessor seeks to identify the types of people using the site, and in particular the critical receptors, who are the most people likely to be exposed or susceptible to the presence of soil contamination.

\section{FUTURE WORK}

Stages 2, 3 and 4 (shown in Fig. 1) remain to be completed and, as such, they are not reported here. Therefore, this section serves to describe insights into the future work. Stage 2 uses a questionnaire to collect primary data in order to validate the conceptual framework with experts who have experience dealing with brownfield sites. The participants will be asked to complete an online survey using Qualtrics online tool.

Stage 3 involves the creation of the DSS tool. Collected data from literature and questionnaire will be used to design the DSS. The DSS will be available as a web-based tool, to make it more accessible for the different users and disseminated to end users. A number of packages have been adopted because they are easy and simple to use and they are open 
source, then the user does not need to pay for licences. The packages are presented as following:

- MySQL databases management: The database has been created to help in identifying and assessing hazards posed to human health and buildings from brownfield sites. The source of database should mainly base on information of highest standard. Two essential sources are adopted in this research which are literature (secondary data) and the knowledge of experts (primary data).

- Hypertext Mark-up Language 5 (HTML5): adopted to structure the webpage by organising information into separate parts such as title, heading, and paragraph.

- Cascading Style Sheets (CSS) will be used to design user interface and functions of the web-based tool.

Stage 4, validation of the DDS tool, facilitated by two approaches, the first validation will be carried out by functional testing, which will involve testing tool inputs and outputs against real-life case studies in order to check accuracy of data outputs. Secondly, the DDS is will be uploaded to the internet, and it will be validated in terms of:

- $\quad$ its graphical user interface;

- the effect of the tool to the user in applying preliminary risk assessment for brownfield sites;

- the level of information provided by the tool;

- how likely the user will use the tool again or recommends it.

\section{CONCLUSION}

Previous academic, professional and government literature has identified a range of obstacles that need to be overcome before residential developments can be approved and built on brownfield sites. Amongst the difficulties facing brownfield site assessors is the need to find and understand health and safety information related to brownfield sites. This study has enabled the creation of a stepwise process of risk assessment, which will culminate into an IT tool available as web-based facility. Its design will support a diverse range of stakeholders, in particular, developers and planning authorities who need a speedy, simple and effective tool at their disposal.

A clear and comprehensive conceptual framework has been created to guide research in this field and, ultimately, to shape the development of the DSS tool validated by experts. The DSS requires site history, surrounding area, existing of obstructions, site geology, site hydrology, site topography and future site use as inputs and produces health and safety issues as outputs. The tool outputs are intended to be used as information to help assessors reflect on the health and safety implications of their development. The validation process will be carried out by functional testing, which will involve testing the tool with brownfield site experts and case studies.

\section{REFERENCES}

[1] Gray, J., Brownfield sites, 2019. www.sustainablebuild.co.uk/brownfieldsites.html.

[2] Wong, C. \& Schulze Baing, A., Brownfield Residential Development in England: What Happens to the Most Deprived Neighbourhoods? Joseph Rowntree Foundation: York, 2010.

[3] Pierce, A., Understanding SDG 11 Indicators for Sustainable Cities and Communities, 2018. www.sopact.com/perspectives/sdg-11-indicators. Accessed on: 8 Jan. 2020. 
[4] Sinnett, D., Carmichael, L., Williams, K. \& Miner, P., From wasted space to living spaces: The availability of brownfield land for housing development in England, 2014.

[5] Ashton, D., Benstead, R., Bradford, P. \& Whitehouse, P., An ecological risk assessment framework for contaminants in soil. Science Report: SC070009/SR1, Environment Agency: Bristol, 2008.

[6] Swartjes, F.A., Human health risk assessment related to contaminated land: State of the art. Environmental Geochemistry and Health, 37(4), pp. 651-673, 2015.

[7] Duruibe, J., Ogwuegbu, M.O.C. \& Egwurugwu, J., Heavy metal pollution and human biotoxic effects. International Journal of Physical Sciences, 2(5), pp. 112-118, 2007.

[8] Augustsson, A. et al., Challenges in assessing the health risks of consuming vegetables in metal-contaminated environments. Environment International, 113, pp. 269-280, 2018.

[9] Charles, J.A., Chown, R.C., Watts, K.S. \& Fordyce, G., Brownfield Development Sites: Ground-Related Risks for Buildings, Building Research Establishment: London, 2002.

[10] Charles, J.A. \& Skinner, H.D., Compressibility of foundation fills. Proceedings of the Institution of Civil Engineers: Geotechnical Engineering, 149(3), pp. 145-157, 2004.

[11] Skinner, H., Charles, J.A. \& Tedd, P., Brownfield Sites: Integrated Ground Engineering Strategy, Building Research Establishment: London, 2005.

[12] UK Environment Agency, Model procedures for the management of land contamination. A research report prepared by Casella Stanger under the Science Project SC02000028 for the UK Environment Agency, 203 pp., 2004.

[13] Martin, J.C. \& Toll, D.G., The development of a knowledge-based system for the preliminary investigation of contaminated land. Computers and Geotechnics, 33(2), pp. 93-107, 2006.

[14] Laidler, D.W., Bryce, A.J. \& Wilbourn, P., Brownfields: Managing the Development of Previously Developed Land: A Client's Guide, Construction Industry Research and Information Association, 2002.

[15] Locatelli, L., Binning, P.J., Sanchez-Vila, X., Søndergaard, G.L., Rosenberg, L. \& Bjerg, P.L., A simple contaminant fate and transport modelling tool for management and risk assessment of groundwater pollution from contaminated sites. Journal of Contaminant Hydrology, 221, pp. 35-49, 2019.

[16] Environment Agency, Guidance for Developments Requiring Planning Permission and Environmental Permits, Environment Agency: Bristol, 2012.

[17] Nathanail, C.P. \& Bardos, R.P., Reclamation of Contaminated Land, John Wiley, 2005.

[18] Neath Port Talbot County Borough Council, Contaminated Land Strategy 2015, 33 pp., 2015.

[19] Burger, J., Mayer, H., Greenberg, M., Powers, C., Volz, C. \& Gochfeld, M., Conceptual site models as a tool in evaluating ecological health: The case of the Department of Energy's Amchitka Island nuclear test site. Journal of Toxicology and Environmental Health: Part A, Current Issues, 69(13), pp. 1217-1238, 2006.

[20] Syms, P., Redeveloping brownfield land: The decision-making process. Journal of Property Investment and Finance, 17(5), pp. 481-500, 1999.

[21] Boddy, M., Designer neighbourhoods: New-build residential development in nonmetropolitan UK cities: The case of Bristol. Environment and Planning A: Economy and Space, 39(1), pp. 86-105, 2007.

[22] Ashraf, M.A., Maah, J.M. \& Yusoff, I., Soil contamination, risk assessment and remediation. Environmental Risk Assessment of Soil Contamination, ed. M.C. Hernandez-Soriano, IntechOpen, 2014. 
[23] DEFRA, Contaminated Land Remediation, DEFRA, pp. 99-105, 2010.

[24] Vik, E.A. \& Bardos, P., Remediation of contaminated land technology implementation in Europe. (Prepared by working group Remediation technologies of the concerted action Contaminated Land Rehabilitation Network for Environmental Technologies (CLARINET).) Umweltbundesamt, 2003.

[25] Syms, P., Previously Developed Land, Wiley, 2007.

[26] Suter II, G.W., Guide for Developing Conceptual Models for Ecological Risk Assessments, US Department of Energy, 21 pp., 1996.

[27] Vik, E. \& Bardos, P., Remediation of Contaminated Land Technology Implementation in Europe: A Report from the Contaminated Land Rehabilitation Network for Environmental Technologies, Federal Environment Agency: Austria, 2002.

[28] Agostini, P. \& Vega, A., Decision support systems (DSSs) for contaminated land management: Gaps and challenges. Decision Support Systems for Risk-Based Management of Contaminated Sites, Springer, p. 1-6, 2009.

[29] Department of the Environment, CLR03 Documentary Research on Industrial Sites, London, 1994.

[30] DEFRA \& Environmental Agency, Model Procedures for the Management of Land Contamination, Environment Agency: Bristol, 2004.

[31] Nunes, L., Zhu, Y.-G., Stigter, T., Monteiro, J. \& Teixeira, M., Environmental impacts on soil and groundwater at airports: Origin, contaminants of concern and environmental risks. Journal of Environmental Monitoring: JEM, 13, pp. 3026-3039, 2011.

[32] Sarsby, R.W., Environmental Geotechnics, Thomas Telford, 2000.

[33] Vik, E.A. et al., Towards a framework for selecting remediation technologies for contaminated sites. Land Contamination and Reclamation, 9(1), pp. 119-127, 2001.

[34] Ministry of Housing, Communities \& Local Government, Guidance: Land affected by contamination, 2014. www.gov.uk/guidance/land-affected-by-contamination. Accessed on: 15 Jul. 2019.

[35] NHBC \& Environmental Agency, Guidance for the Safe Development of Housing on Land Affected by Contamination, R \& D Publication 66: Volume 1, 2008.

[36] Nathanail, J., Bardos, P. \& Nathanail, P., Contaminated Land Management: Ready Reference, EPP Publications, 2011.

[37] Neta, G. et al., A framework for enhancing the value of research for dissemination and implementation. American Journal of Public Health, 105(1), pp. 49-57, 2015. 